\title{
Rural - urban income gap and labour market in Romania
}

\author{
Irina Băncescu, ${ }^{1, *}$ \\ ${ }^{1}$ National Institute for Economic Research “Costin C. Kirițescu”, Calea 13 Septembrie, no.13, \\ Bucharest, Romania 050711
}

\begin{abstract}
Rural - urban income gap is an important social-economic development indicator for a society. A large rural - urban income gap within a society reveals a split of it into two distinct societies, one extremely poor compared to the other. In Romania, almost half of the resident population lives in rural areas (46.02\% in 2019), while the urbanrural migration flow is higher than the traditional reverse flow since 1997. However, the country is characterized by regional economic disparities, Bucharest-Ilfov region being the most economically developed. Labour market in rural areas is underdeveloped, rural population being highly depended on subsistence agriculture. Furthermore, rural areas have a low level of income and living standards. In this paper, we analysis the ruralurban labour market dynamics and rural-urban income gap using a LMDI (logarithmic mean Divisia index) decomposition for 2005-2019 period. Factors such as income gap effect and structural rural income effect are considered. Results show that the total urban-rural income gap has decreased with $8.91 \%$, while structural rural income effect contributed with an increase of only $0.63 \%$, the income gap effect (of different employed population groups) being of $-9.49 \%$.
\end{abstract}

Keywords: rural-urban income gap; LMDI decomposition; rural development

JEL Classification: $J 01 ; J 08 ; J 31$

* Corresponding author: irina adrianna@yahoo.com 


\section{Introduction}

Rural development is as important to a country as urban development. However, increasingly economic and social development gaps between rural and urban areas were observed in many countries in the last years posing serious challenges in societies. A large rural - urban income gap within a society reveals a split of it into two distinct societies, one extremely poor compared to the other.

European Union has addressed rural development improvement through its Rural Development Programmes (RDPs). Romania's 2014-2020 Rural Development Programme has as main priorities increasing the competitiveness of agricultural sector, job creation in rural areas, and environmental protection. Several studies have addressed the factors influencing rural development which include poor infrastructure, lack of social and financial capital $[1,2]$. Rural development can be achieved by promoting technological innovation and tourism [3-6].

Dinu et al. [7] analyzed the absorption of 2014-2020 European funds destined for rural development in Romania and concluded that most of the financial support went to renovation and development of villages, support for young farmers and for agricultural exploitations.

Ciutacu et al. [8] performed a comparative analysis between Romanian agriculture sector and the rest of EU member states agriculture sectors and concluded that without proper policy and support the Romanian agriculture cannot compete in the EU common market.

Rural-urban income gap has as consequence reallocation of rural labour and depopulation of rural areas [9]. Furthermore, agriculture growth is effected by the ruralurban income gap [10]. Various studies have showed that there is a link between rural poverty reduction and agricultural labour productivity, this link depending on regional background [11-14].

The paper is organized as follows. In Section 2 we present the logarithmic mean Divisia index (LMDI) decomposition of urban-rural relative income gap, along with data used. Section 3 concerns the discussion of results.

\section{Methodology}

\subsection{Data}

Variables used in this paper are average monthly income for employees, self-employed and farmers from National Institute of Statistics (2005-2019) [15]; employed, self-employed and employees population an economic activities and urban, rural areas from Eurostat database (2005-2017) [16]; GDP at current market prices (million euro) of urban and rural areas from Eurostat database (2007-2017); at risk-of-poverty thousands of people by degree of urbanization (2007-2017) [16]. Variables and time periods in this paper are chosen based on their availability.

\subsection{Logarithmic mean Divisia index (LMDI) decomposition}

Urban-rural relative income gap decomposition based on logarithmic mean Divisia index method (LMDI) $[17,18]$ is as follows: 


$$
\frac{\text { UrbanIncome }_{\text {RuralIncome }}}{\text { Ru }_{\mathrm{i}=1}^{3}} \frac{\text { UrbanIncome }_{\mathrm{i}}}{\text { RuralIncome }_{\mathrm{i}}} \times \frac{\text { RuralIncome }_{\mathrm{i}}}{\text { RuralIncome }_{i=1}^{3}}=\sum_{i} I G_{i} \times R S I_{i}
$$

where UrbanIncome $e_{i}$ is the average monthly income for employed category $i$ (employees, self-employed and farmers) in urban areas. RuralIncome ${ }_{i}$ represents the average monthly income for employed category $i$ in rural areas. $I G_{i}=\frac{\text { UrbanIncome }_{i}}{\text { RuralIncome }_{i}}$ is the urban-rural relative income gap for employed category $i ; R S_{i}=\frac{\text { Ruralincome }_{i}}{\text { Ruralincome }}$ represents the share of average monthly income for employed category $i$ in rural income.

LMDI decomposition of urban-rural relative income gap for period from $t$ to $t+1$ is

$$
D_{t o t, t+1}=\frac{\text { Urban }- \text { rural relative income gap }}{t+1}=D_{\text {gap }, t+1} \times D_{\text {str }, t+1}^{\text {Rural }}
$$

where $D_{g a p, t+1}$ is the estimated impact of structural urban-rural relative income gap, $D_{\text {str }, t+1}^{\text {Rural }}$ is the estimated impact of rural structural income, while $D_{t o t, t+1}$ is the represents the total effect of urban-rural relative income gap. We have the following

$$
\begin{aligned}
& D_{s t r, t+1}=\exp \sum_{i} \frac{L\left(\omega_{i, t+1}, \omega_{i, t}\right)}{\sum_{i} L\left(\omega_{i, t+1}, \omega_{i, t}\right)} \times \log \left(\frac{I G_{i, t+1}}{I G_{i, t}}\right) \\
& D_{s t r, t+1}^{\text {Rural }}=\exp \sum_{i} \frac{L\left(\omega_{i, t+1}, \omega_{i, t}\right)}{\sum_{i} L\left(\omega_{i, t+1}, \omega_{i, t}\right)} \times \log \left(\frac{R S I_{i, t+1}}{R S I_{i, t}}\right)
\end{aligned}
$$

where $L(x, y)=\frac{x-y}{\log (y)-\log (x)}$, and $\omega_{i, t}=\frac{\text { UrbanIncome }_{i, t}}{\text { UrbanIncome }_{t}}$.
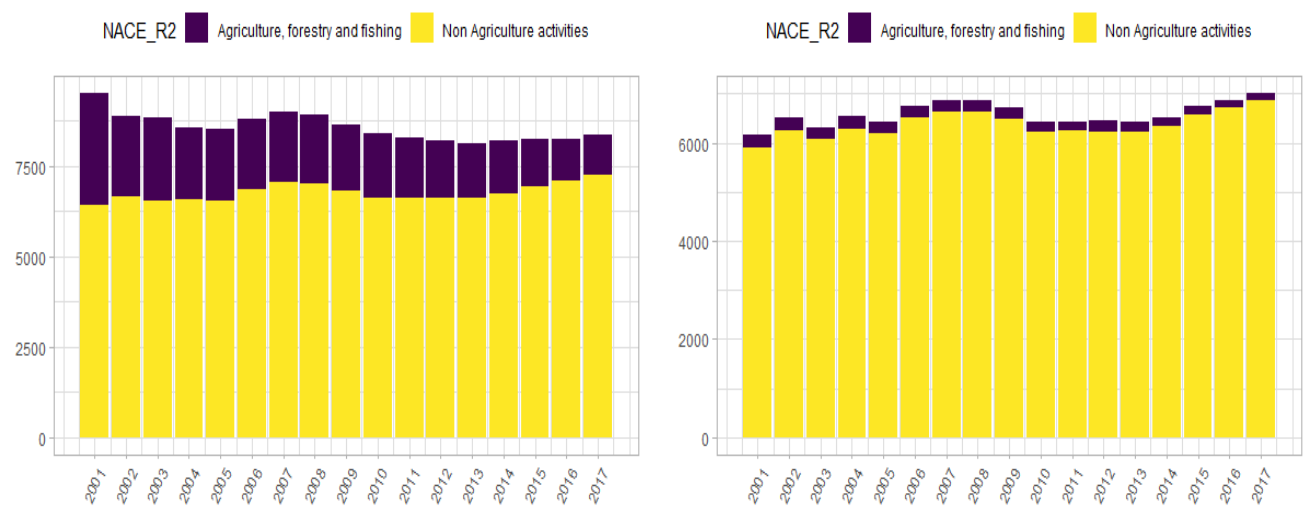

Fig. 1. Urban (left) and Rural (right) employed population in agriculture and non-agriculture activities. Source: Authors' own calculations based on RStudio. 


\section{Results}

The dynamics of urban-rural labour market in Romania is characterized by a lack of employment opportunities in rural areas. Furthermore, the number of employees is significantly lower in rural areas than in urban areas. At the beginning and end of the period selected (2005-2017), the share of employees in rural areas was $30.73 \%$ in 2005 and $29.66 \%$ in 2017 , while urban areas has a strong number of employees (around $70 \%$ ) (Figures 1-3). The fast majority of rural employed population was self-employed $(49.10 \%$ in 2005 and $52.72 \%$ in 2017, the rest being in urban areas). Also, agriculture labour market is characterized by a low number of employees $(5.06 \%$ in 2005 and $3.41 \%$ in 2017$)$ and by a high share of self-employed (88.16\% in 2005 and $78.16 \%$ in 2017). Share of employed population in rural areas was $36.38 \%$ in 2005 which dropped to $34.77 \%$ in 2017 .
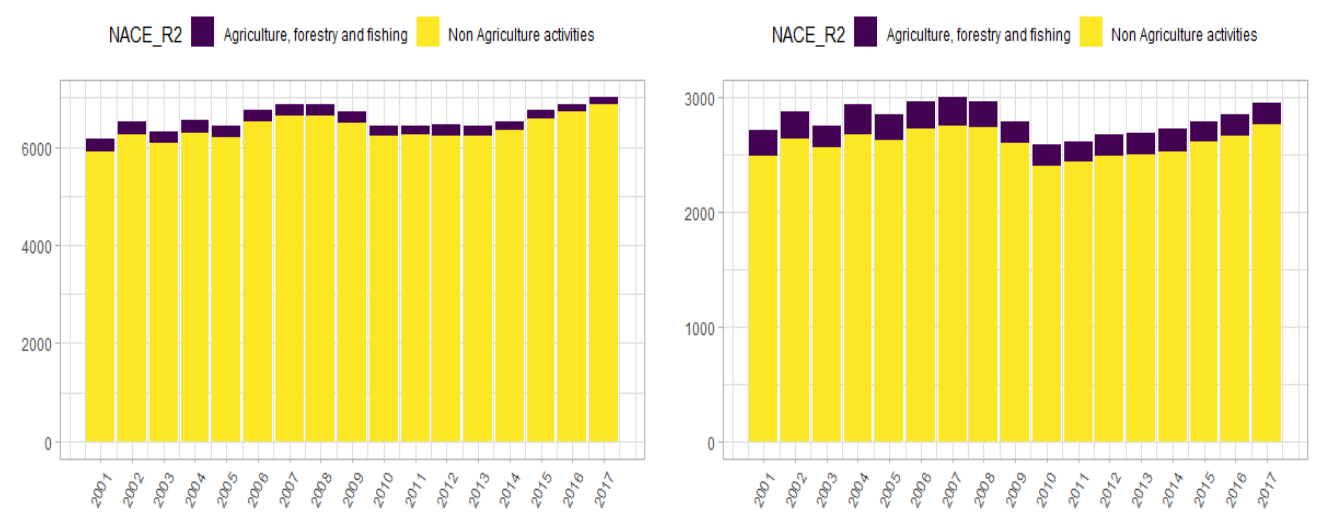

Fig. 2. Urban (left) and Rural (right) employees population in agriculture and non-agriculture activities. Source: Authors' own calculations based on RStudio.
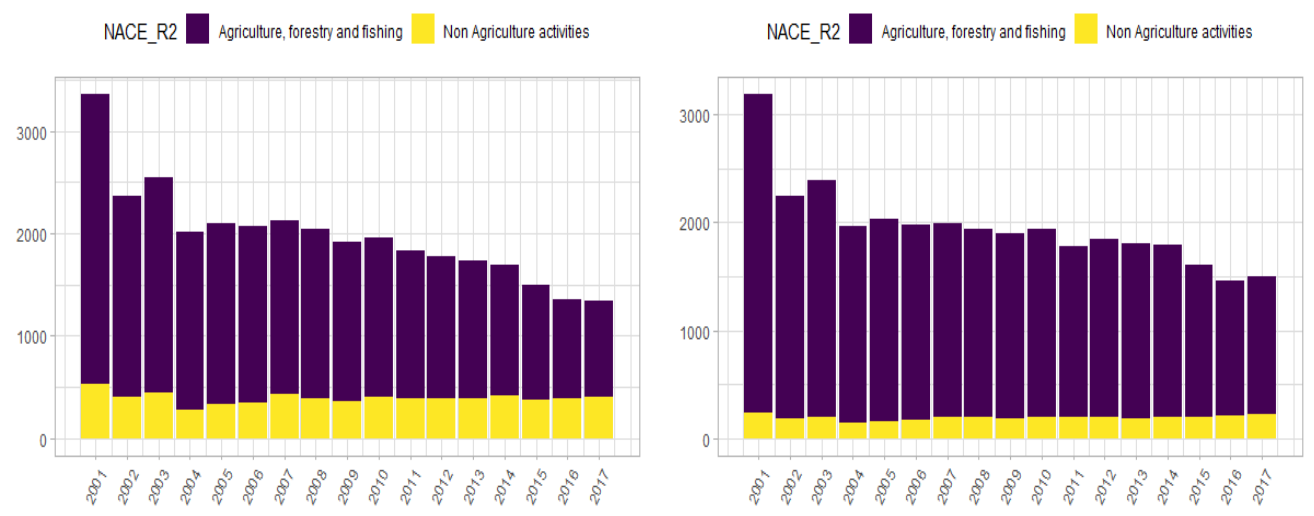

Fig. 3. Urban (left) and Rural (right) self- employees population in agriculture and non-agriculture activities. Source: Authors' own calculations based on RStudio.

LMDI decomposition results are displayed in Table 1. The urban-rural relative income gap has decreased during the 2005-2019 with an average of $-0.6 \%$ annually resulting a total decrease of $-8.91 \%$. The relative income gap between different types of employed individuals has had a decreasing effect on total urban-rural relative income gap while the 
rural structural income factor contributed to an increased of urban-rural relative income gap by an insignificant of $-0.3 \%$ on average annually for a total increase of $0.63 \%$. Urban-rural relative income gap has decreased by a total of $-9.49 \%$. The results suggests that income structural of different employed category did not have an effect in reducing urban-rural inequality. However, the gap between different employed categories, between urban and rural areas, has decreased and so did the urban-rural income relative gap. While urban-rural relative income gap for farmers and self employed has a small decreases, for employees this decrease was larger (from 1.37 in 2005 to 1.27 accounting a $-7.29 \%$ decrease). However, while the relative income gap decreased the absolute income gap increased.

Urban-rural absolute income gap is defined as the difference between urban income and rural income. This absolute income gap for average monthly income increased from 74.93 RON to 169.94 RON $(+126 \%)$ for farmers from 2005 to 2017 . For self employed increased from $335.89 \mathrm{RON}$ to $790.75 \mathrm{RON}(+135 \%)$, while for employees from $424.04 \mathrm{RON}$ to $1029.31(+142.73 \%)$.

Table 1. Urban-rural income gap decomposition

\begin{tabular}{|c|c|c|c|}
\hline Year & Total effect & $\begin{array}{c}\text { Income Gap } \\
\text { effect }\end{array}$ & $\begin{array}{c}\text { Rural } \\
\text { Structural } \\
\text { effect }\end{array}$ \\
\hline $2005-2019$ & 0.910 & 0.905 & 1.006 \\
\hline Mean & 0.994 & 0.994 & 1.003 \\
\hline Median & 0.980 & 0.981 & 0.999 \\
\hline Min & 0.910 & 0.907 & 0.996 \\
\hline Max & 1.078 & 1.079 & 1.004 \\
\hline $\begin{array}{c}\text { Standard } \\
\text { deviation }\end{array}$ & 0.05 & 0.05 & 0.002 \\
\hline
\end{tabular}

Source: Authors' own calculations based on RStudio.

Since agriculture growth is effected by the rural-urban income gap, a stronger agriculture sector should reduce the rural-urban economic gap. Spearman correlation rank coefficient between at risk-of -poverty thousands of people living predominantly in rural areas and GDP generated by rural areas is -0.6 ( $\mathrm{p}$-value $=0.05)$. Therefore, between poverty and economic growth exists a negative linear correlation in rural areas of Romania. Cooperatives can contribute to reduce poverty. Ma and Abdulai [19] through their analysis of rural agriculture cooperatives in China have showed that being a cooperative member benefits the gross income, return in investment and profitability. Associations in agriculture contribute to greater power of negotiation, lower production costs and a better context for innovation [20].

\section{Acknowledgement}

This paper received financial support through the project entitled "DECIDE Development through entrepreneurial education and innovative doctoral and postdoctoral research, project code POCU / 380/6/13/125031, project co-financed from the European Social Fund through the 2014 - 2020 Operational Program Human Capital” 


\section{References}

1. Galluzzo N. (2018) Impact of the Common Agricultural Policy payments towards Romanian farms. Bulgarian Journal Agricultural Science, 24(2), 199-205.

2. Galluzzo, N. (2018). A preliminary quantitative analysis of rural development in Romania using the PLS-SEM. Albanian Journal of Agricultural Sciences, 17(3), 125133.

3. Muresan, I.C., Harun, R., Arion, F.H., Oroian, C.F., Dumitras, D.E., Mihai, V.C., Ilea, M., Chiciudean, D.I., Gliga, I.D., Chiciudean, G.O. (2019) Residents' perception of destination quality: Key factors for sustainable rural development. Sustainability, 11(9), 2594.

4. Liu, Y., Long, H., Chen, Y., Wang, J., Li, Y., Li, Y., Yang, Y., Zhou, Y. (2016) Progress of research on urban-rural transformation and rural development in China in the past decade and future prospects. Journal of Geographical Sciences, 26(8), 11171132.

5. Yin, X., Chen, J., Li, J. (2019). Rural innovation system: Revitalize the countryside for a sustainable development. Journal of Rural Studies.

6. Jordan, P., Havadi-Nagy, K. X., Maroşi, Z. (2016). Tourism as a driving force in rural development: Comparative case study of Romanian and Austrian villages. Turizam: međunarodni znanstveno-stručni časopis, 64(2), 203-218.

7. Dinu, M., Pătărlăgeanu, S. R., Chiripuci, B., Constantin, M. (2020). Accessing the European funds for agriculture and rural development in Romania for the 2014-2020 period. In Proceedings of the International Conference on Business Excellence (pp. 717-727). Sciendo.

8. Ciutacu, C., Chivu, L., Andrei, J. V. (2015). Similarities and dissimilarities between the EU agricultural and rural development model and Romanian agriculture. Challenges and perspectives. Land Use Policy, 44, 169-176.

9. Zhang, K. H., Shunfeng, S. O. N. G. (2003). Rural-urban migration and urbanization in China: Evidence from time-series and cross-section analyses. China Economic Review, 14(4), 386-400.

10. Gao, Y., Zheng, J., Bu, M. (2014). Rural-urban income gap and agricultural growth in China. China Agricultural Economic Review.

11. De Janvry, A., Sadoulet, E. (2010). Agricultural growth and poverty reduction: Additional evidence. The World Bank Research Observer, 25(1), 1-20.

12. Rehman, A., Jingdong, L., Khatoon, R., Iqbal, M. S., Hussain, I. (2019). Effect of agricultural growth on poverty reduction, its importance and suggestions. Transylvanian Review, (7).

13. Mellor, J. W., Malik, S. J. (2017). The impact of growth in small commercial farm productivity on rural poverty reduction. World Development, 91, 1-10.

14. Van den Broeck, G., Maertens, M. (2017). Moving up or moving out? Insights into rural development and poverty reduction in Senegal. World Development, 99, 95-109.

15. National Institute of Statistics of Romania TEMPO Online database (access on 07 September 2020)

16. Eurostat database (access on 07 September 2020)

17. Chen, J., Rong, S., Song, M. (2020). Poverty Vulnerability and Poverty Causes in Rural China. Social Indicators Research, 1-27. 
18. Li, T., Yu, W., Baležentis, T., Zhu, J., Ji, Y. (2017) Rural demographic change, rising wages and the restructuring of Chinese agriculture. China Agricultural Economic Review, 9(4). 478-503.

19. Ma, W., Abdulai, A. (2017). The economic impacts of agricultural cooperatives on smallholder farmers in rural China. Agribusiness, 33(4), 537-551.

20. Crețu, O.R., Tudor V.C. (2020). Economic and social impact of associations in groups of agricultural producers-a case study in Romania. Scientific Papers SeriesManagement, Economic Engineering in Agriculture and Rural Development, 20(2), 183-190. 